\title{
A személyre szabott terápia legújabb lehetőségei a molekuláris onkológiában
}

\author{
Menyhárt Otília, Vas Virag*, Győrffy Balázs, Buday László \\ Természettudományi Kutatóközpont, Enzimológiai Intézet, Budapest, Magyarország \\ Beérkezett: 2021. május 07.; Elfogadva: 2021. május 26.
}

\begin{abstract}
Összefoglalás
A molekuláris onkológia térnyerésével számos új lehetőség érhetô el a daganatos betegek hatékonyabb kezelésére. Ilyen a klinikai vizsgálatokban alkalmazott, a valóban személyre szabott kezelést elősegítő génpanelelemzés, illetve a célzott kezelés szövettípustól független alkalmazása. A személyre szabott terápiák jelentős hányada valamelyik kinázt gátolja. Az összefoglalónkban bemutatjuk a RAS jelátviteli út sejten belüli komplex szabályozását, valamint ismertetjük az útvonal további farmakológiai szempontból kiaknázható célpontjait nemzetközi és saját eredményeink alapján. A kinázokat érintő gyakori mutációk ellenére számos daganattípusban nem áll rendelkezésre személyre szabott terápia. A hagyományos terápiáaal nem kezelhető agydaganatok példáján keresztül bemutatjuk a tirozin-kinázok várható jövőbeli terápiás jelentőségét.
\end{abstract}

Kulcsszavak: célzott terápia, szolid tumorok, mutáció, onkogén, jelátviteli útvonal, kináz-gátlás

\author{
New Options for Personalized Treatment in Molecular Oncology \\ Otília Menyhárt, Virag Vas, Balázs Győrffy, László Buday \\ Research Centre for Natural Sciences, Institute of Enzymology, Budapest, Hungary
}

\begin{abstract}
Summary
With the advent of molecular oncology, the identification of mutations in solid tumours is now clinically routine. The growing repertoire of targeted therapeutic agents has supported the rise of a new type of clinical trial in which the selection of the therapeutic agent is no longer restricted to a single option. Instead, a panel of genes is screened to identify the most suitable drug for each patient. Such trials have delivered objective response rates in $5-30 \%$ of patients. Most of the signal transduction pathways targeted by these agents involves RAS signaling.

Somatic mutations in RAS genes are common in human tumours. Such mutations generally decrease the ability of RAS to hydrolyze GTP, maintaining the protein in a constitutively active GTP-bound form that drives uncontrolled cell proliferation. Recent emerging data suggest that RAS regulation is more complex than the scientific community has appreciated for decades. We discuss a novel type of RAS regulation that involves direct phosphorylation and dephosphorylation of RAS tyrosine residues. The discovery that pharmacological inhibition of the tyrosine phosphoprotein phosphatase SHP2 maintains mutant Ras in an inactive state suggests that SHP2 could be a novel drug target for the treatment of Ras-driven human cancers.

In addition to RAS gene mutations, other common oncogenic events have also been identified, including mutation of EGFR (epidermal growth factor receptor) or BRAF (isoform B of rapidly accelerated fibrosarcoma). EGFR has tyrosine kinase activity while BRAF acts as a serine/threonine kinase. In some tumours, mutant forms of these kinases over-activate cell proliferation, leading to uncontrolled tumour cell growth; therefore, it seems rational to develop inhibitor molecules that target these hyper-active oncogenic kinases to reduce tumour cell burden in cancer patients.

Fusion protein kinases activated via the RAS pathway represent target proteins with high clinical success rates. Recently approved TRK fusion protein kinase inhibitors have reached response rates in almost $80 \%$ of patients regardless of tumour type. Although these drugs can only be administered to patients whose tumours harbour a TRK fusion protein, such success stories pave the way for future development of agents that target similar genetic mutations.

Glioblastoma multiforme, a relatively frequent, almost uniformly fatal brain tumour, has ubiquitous alterations in tyrosine-kinase signalling. Nevertheless, to this day, no tyrosine-kinase inhibitors have been approved for its treat-
\end{abstract}


ment. We have ongoing research projects to uncover associations between initial gene expression levels in untreated glioblastoma samples and treatment-related survival, and we have identified overexpression of druggable tyrosinekinase receptors in chemotherapy-resistant patients. Our approach will help to identify patients who might benefit from concurrent use of tyrosine kinase inhibitors and conventional cytotoxic therapies.

Keywords: targeted therapy, tumour cells, oncogenic mutations, signal transduction, kinase inhibition

\section{Molekulárisan célzott terápia - klinikai vizsgálatok}

A rosszindulatú tumorok létrejöttének alapvető, széles körben elfogadott és tankönyvi oktatásban is szereplő alapja az egy sejtben bekövetkező mutáció. Ezen első mutáció általában a sejtosztódás sebességét kezdi el gyorsítani, ami ezután lehetővé teszi, hogy további mutációk jöjjenek létre. Ezen mutációk egyrészt a sejtosztódás folyamatát gyorsítják tovább, másrészt pedig lehetôvé teszik a rosszindulatú tumorokra jellemző biológiai funkciók beindítását. Munkánk során nem célunk ezen változások áttekintése, azonban egy kritikus tényezőt ki kell emelni: a fentebb leírt tumorigenezis legfontosabb eredménye, hogy a tumorsejtek mindegyike fog olyan mutációt tartalmazni, amely megkülönbözteti a szervezet egészséges sejtjeitôl. Ezen mutációk és genetikai eltérések kihasználása a molekulárisan célzott terápia alapja. Amennyiben egy olyan gyógyszert adunk, amelyik csak azon sejtek osztódását állítja le, amelyek a tumorban vannak, akkor az egészséges szövetekben várható mellékhatások aránya minimális lesz.

Azonban itt ki kell emelni, hogy sokféle tumorsejt alkot egy tumort a betegben, tehát a heterogén tumorsejtek keverékében sokféle mutáció van jelen egyszerre és genetikai eltérések eloszlása nem egyenletes. Elméleti síkon mozogva is csak annyit tudunk biztosan, hogy egy adott mutáció az eredeti ráksejt osztódása után a leszármazott-sejtekben lesz jelen, de a tumor többi sejtjében nem lesz megtalálható, így a célzott terápiás gyógyszeres kezelések során cél olyan molekuláris támadáspontot választani, amelyik a tumorsejtek lehető legnagyobb arányában van jelen. Ez azonban sokszor nem lehetséges, mivel a diagnóziskor a tumor már sokszor évek óta jelen volt, és ez idő alatt számos mutációt begyújthetett. A tumor kialakulása során eltelő évek, illetve évtizedek alatt maga a tumor egymással versengő sejtvonalak gyújteményévé alakulhatott. Ennek az a következménye, hogy amikor a tumorsejteket molekuláris genetikai módszerekkel megvizsgáljuk és a mutációkat azonosítjuk, akkor tipikus esetben több olyan elváltozást is találhatunk, amelyekre rendelkezésre áll már célzott gyógyszer.

Kérdésként vetődik fel tehát, hogy egy újonnan diagnosztizált tumoros betegben hogyan válasszuk ki azt a gyógyszert, amelyiknek a legnagyobb lesz a várható klinikai haszna? Erre mind a mai napig nem áll rendelkezésre megbízható módszer, és egyetlen klinikai protokoll sincsen elfogadva, amely sok gén egyidejű vizsgálatával próbálná az összes szóba jövő kezelési lehetőséget összevetni.

Az ilyen irányú klinikai vizsgálatok azonban már folyamatban vannak. A legnagyobb és legjelentősebb ilyen próbálkozás az NCI-MATCH $(\mathrm{MATCH}=$ Molecular Analysis for Therapy Choice) vizsgálat (Flaherty et al. 2020). Ebbe a kutatásba olyan betegeket vontak be, akiknél előrehaladott vagy recidív tumor jelent meg, és a rosszindulatú tumor szövettani szempontból szolid tumor, lymphoma vagy myeloma volt. Valamennyi betegből meghatározták 143 gén mutációs állapotát, valamint néhány kiemelt gén esetén mikroszkópos vizsgálatot, vagyis rutin immunhisztokémiai festést is végeztek. Amennyiben találtak klinikailag is célozható mutációt, akkor a betegeket ezen elváltozásnak megfelelő gyógyszerrel kezelték. A főbb vizsgált eltérések között ismert gének szerepeltek, mint ERK, BRAF, MEK, PI3K, TRK, FGFR stb.

A vizsgálatba összesen 795 beteget vontak be, és a betegek $87 \%$-ában sikerült a molekuláris genetikai vizsgálatot elvégezni. Ki kell emelni, hogy a betegek 13\%-ából nem sikerült a mérést elvégzeni. Ennek több oka is lehet: például a mintavétel során nem sikerült egyértelmû́ tumorszövetet kiemelni, és ezért a normál sejtekkel való keveredés magas fokú volt, vagy pedig a szöveti elhalás miatt nem lehetett éló tumorsejteket találni. Azt is meg kell említeni, hogy mivel ezen vizsgálat nem a kezelési protokoll része, ezért csak akkor lehetett elvégezni a molekuláris genetikai mérést, ha a rutindiagnosztikára már elkülönítettek megfelelő tumormennyiséget. A molekuláris vizsgálatnak alávetett minták 8,7\%-ában találtak olyan elváltozást, amelyik alapján a beteget az egyik kezelési karba lehetett beosztani, és ezen betegek 59\%-a kapta meg a tényleges kezelést. Bár ezek a számok viszonylag magasnak tünnek, azonban ha visszavetítjük az eredeti számra, amely az összes bevont beteget tartalmazza, akkor azt látjuk, hogy a vizsgálatba bevont betegek kicsivel kevesebb mint 5\%-a kapott olyan kezelést, amely esetén klinikai javulásra lehet számítani.

Ismeretes, hogy alapvetően eltérnek a felnőttkori és a gyermekkori daganatok: miközben a felnőttkori tumorokban nagyfokú a genetikai heterogenitás, addig a gyermekkori tumorokban viszonylag kevés mutációt sikerült azonosítani (Vogelstein et al. 2013). Számokban meghatározva: miközben egy tüdődaganatban 100-500 mutációt lehet azonosítani, egy kolontumorban pedig akár 1500 mutációt, addig egy gyermekkori glioblastoma vagy szarkóma mögött mindössze $2-10$ darab mutáció áll (Vogelstein et al. 2013). Ennek oka, hogy a gyermek- 
kori tumorok sokkal rövidebb idő alatt alakulnak ki egy erósebb mutagén hatásra, ezért egyszerúen nem áll rendelkezésre elegendő idő a tumorsejtek számára a nagyfokú heterogenitás elérésére.

Azonban a gyermekkori tumorok ezen tulajdonsága felveti annak lehetőségét, hogy a molekulárisan célzott terápiák ezen betegekben nagyobb hatékonysággal vethetőek be. Ennek kiderítésére indította el az Amerikai Rákkutató Intézet a „Pediatric MATCH” vizsgálatot (Parsons et al. 2019), amely a fentebb leírt MATCH vizsgálat mintájára, azonban kizárólag 1 és 21 év közötti betegek bevonásával jelenleg is fut. A vizsgálatban 160 gén mutációit határozzák meg, és évente kb. 300 beteg bevonása a cél. Bár végleges eredmények még nincsenek, azonban 370 vizsgált beteg utáni köztes eredményeket már nyilvánosságra hoztak. Ebben azt írták le, hogy a gyermekek 29\%-ában tudtak olyan genetikai elváltozást azonosítani, amelyek terápiásan is megcélozhatóak, és a betegek negyede ténylegesen is megkapta valamelyik kezelést.

A gyermekekben levő magasabb találat egyik oka lehet a tumorok kisebb heterogenitása. Amit itt ki kell emelni, hogy a tumor összetételének vizsgálata során arányokról beszélünk. Tehát az adott mutációnak a tumoron belül (!) is el kell érnie egy bizonyos mennyiséget, ami után már klinikai haszonra lehet számítani (Gieszer et al. 2021). Miközben a gyermekkori tumorokban ennek az elérése sokkal könnyebb, azonban a felnőttkori heterogenitás a hátrány mellett egy előnyt is rejt magában: további szerek alkalmazását teszi lehetóvé. Pontosan hogyan hatnak ezek a szerek? Az alábbiakban összefoglaljuk a RAS jelátviteli utat, mert a legtöbb molekulárisan célzott terápia során olyan kezelést alkalmazunk, ahol a RAS útvonal valamelyik génje is érintett. Majd rátérünk arra a két, ugyancsak gyakori onkológiai génmutációra, ami a BRAF gént és az EGFR fehérje génjét érinti. Mindkét molekula a BRAF-ban és az EGFR fehérje is egy enzim, melynek sejten belüli specifikus funkcióját célzott inhibitorok használatával le lehet gátolni. Így számba vesszük a molekuláris onkológiában kifejlesztett BRAF és EGFR inhibitor molekulákat.

\section{A RAS jelátviteli út}

Az emberi szervezet mintegy 37 milliárd sejtjének osztódását és differenciálódását sok esetben az úgynevezett receptor tirozin kinázokon keresztül múködő jelpályák szabályozzák. E molekuláris jelpályák egyik legfontosabb szabályozói a RAS fehérjék, amelyek emberi daganatokban gyakran sérülnek, mutálódnak. A RAS-fehérjecsalád tagjai kis molekulatömegü fehérjék, amelyek a sejtek növekedését, túlélését és differenciálódását befolyásolják, míg múködésük során képesek elhasítani a hozzájuk kötődő GTP-t GDP-re és foszfát molekulára. A GTP hasításával a RAS fehérjék két állapotban vannak jelen a sejtekben: GDP-hez kötve inaktív a RAS, míg GTP-hez kötve aktív a RAS fehérje. Három emberi RAS gén van az emberi sejtekben, amelyek négy, nagyon hasonló fehérjét kódolnak: H-RAS, N-RAS, valamint K-RAS4A és K-RAS4B. Utóbbi két fehérje ugyanabból a K-RAS génből íródik át eltéró mechanizmussal (ún. alternatív hasítással). A RAS génen belül a 12., 13. vagy 61. kodont érintő változások az emberi rákos megbetegedések leggyakoribb mutációi közé tartoznak. A RAS fehérjék altípusai közötti nagyfokú hasonlóság ellenére a K-RAS a leggyakrabban mutálódó fehérje.

A RAS gének hibái gyakoriak az emberi daganatokban, különösen hasnyálmirigy-, vastagbél- és az ún. nem kissejtes tüdőrákban. Az ilyen hibák általában csökkentik a RAS azon képességét, hogy elhasítsa a GTP-t, így fenntartja a fehérje állandóan aktív, GTP-hez kötött formáját. A hibásan túlmúködő RAS fehérje olyan jelzést közvetít a sejtekben, ami serkenti a sejtnövekedést és a sejtek külső fékek nélküli szabályozatlan osztódását. Ez vezet végső soron a rákos sejtek megjelenéséhez. A normál RAS fehérje aktiválódásának mechanizmusát az 1990-es években fedezték fel az EGF (epidermális növekedési faktor) jelpálya tanulmányozása közben (Buday-Downward 1993) (1. ábra). EGF kötődés hatására a receptor (EGFR) dimerizálódik és autofoszforilálódik a sejtek plazmamembránjában. Ezt követően a tirozin aminosav oldalláncokon foszforilált receptorhoz olyan jelátviteli molekulák tudnak kötődni, amelyek ún. SH2 doménnel rendelkeznek. Ilyen fehérje a Grb2, amely egy SH2 és két SH3 doménnel rendelkezik. A Grb2 kötődik a foszforilált EGFR-hoz SH2 doménjén keresztül, míg $\mathrm{SH} 3$ doménjeivel megköti a RAS legjobban ismert szabályozó fehérjéjét az SOS-t (RAS guanin nukleotid kicserélő faktora). Ezen a mechanizmuson keresztül az SOS a plazmamembránban elhelyezkedő RAS fehérje közelségébe kerül, amikor is aktiválni tudja a GTP-kötő fehérjét.

Bár a mutáns RAS fehérjecsaládot az első daganatot okozó gének (ún. onkogének) között azonosították, a mai napig nincsen olyan gyógyszer, amely a hibás RAS fehérjéken keresztül támadná a rákos sejteket. Olyan gátlószerek kifejlesztésére lenne szükség, amelyek képesek megakadályozni a RAS fehérje GTP kötődését, így a rákos sejtekben jelen levő állandóan aktív RAS fehérje múködését megfékezni. Jelenleg számos K-RAS inhibitor molekula került azonosításra és publikálásra, fóleg az elmúlt 3-4 évben, azonban ezek közül egyik sem kapott még gyógyszerhatóságtól engedélyt (Moore et al. 2020). Ezek a molekulák a hibás K-RAS fehérjéhez irreverzibilisen, vagyis nem visszafordítható módon kötődő gátlószerek, amelyek egyben szelektívek is. Úgy is fogalmazhatunk, hogy csak azon K-RAS fehérjéket blokkolják, amelyek egy bizonyos génmutáció következtében termelődnek hibásan, a többi RAS fehérjét azonban nem. A klinikai kutatás fázisában legtovább az Amgen nevú potenciális gyógyszer jutott, amely a K-RAS G12C inhibitora, jelenleg fázis II vizsgálatban tesztelik.

A RAS fehérjék szabályozásának egy új típusát fedezték fel az elmúlt években, amely újfajta gyógyszerfejlesztés reményét hordozza magában (összefoglalva: Buday- 


\section{A tumorsejtek szabályozatlan osztódását segítő jeltovábbító molekulák a kináz inhibitor terápiák célpontjai}

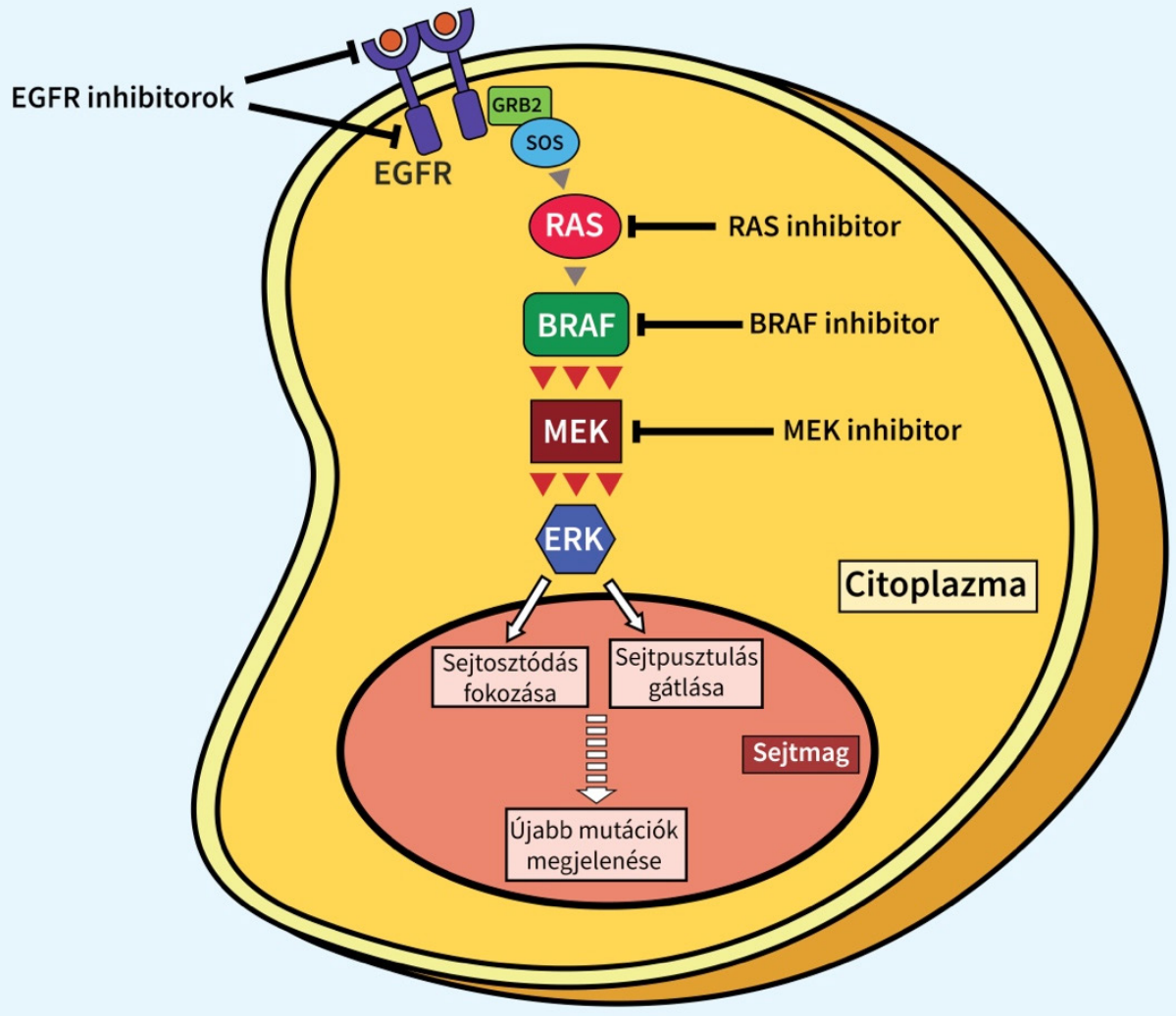

1. ábra

Az EGF receptorról (EGFR) induló sejtosztódást szabályozó jeltovábbító rendszer sematikus rajza. Az EGFR, miután megkötötte ligandumát, az EGF-et képes összekapcsolódni a GRB2 fehérjével. Az SOS fehérje segítségével a RAS molekula aktiválódik, és a BRAF, majd MEK, ERK kinázok aktivitása révén a sejtosztódást elindító jel a sejtmagba jut. A jeltovábbító rendszer molekuláinak mutációja túlaktív kináz molekulákat eredményezhet, melyek a sejtosztódást felerősítik. Célzott terápiával, az egyes komponensek gátlásával az inhibitor molekulák lecsendesíthetik a mutált jeltovábbító molekulák onkogén hatását

Vas 2020). Ennek lényege, hogy nem a GTP kötést gátoljuk az inhibitor molekulával, hanem az aktív állapotú RAS múködését blokkoljuk. Ez úgy lehetséges, hogy az aktív, GTP-kötött RAS-ban olyan szerkezeti változások lépnek fel, melyek lehetóvé teszik a fehérje 32. és 64. tirozin oldalláncainak az Src-kináz függő foszorilációját. Az így foszforilált RAS inaktívvá válik, s nem képes a növekedési jelet tovább közvetíteni. Normál sejtekben a RAS-ciklus újbóli elindítását az SHP2 foszfatáz enzim idézi elő, amely lehasítja a RAS-en található foszfátcsoportokat. Tekintve, hogy a daganatsejtekben állandóan aktív, GTP-kötött hibás RAS is képes foszforilálódni, ezáltal gátlódni, kihasználhatjuk ezt a képességüket és célzott szerekkel a mutáns RAS fehérjét foszforilált állapotban tarthatnánk. A RAS molekulák defoszforilációjának megakadályozásával végső soron leállíthatnánk a ráksejtek osztódását. Ilyen foszfatáz inhibitor molekulák fejlesztése intenzíven folyik, megcélozva az SHP2 enzim gátlását, és remélhetőleg áttörést fognak jelenteni a hibás RAS fehérjék okozta daganatok terápiájában (1. táblázat). \begin{tabular}{l|l} 
1. táblázat & RAS fehérje gátló molekulák, valamint EGFR és BRAF kináz
\end{tabular} inhibitorok összegzése

\begin{tabular}{lll}
\hline & $\begin{array}{l}\text { Kis molekulájú } \\
\text { gátlószerek }\end{array}$ & $\begin{array}{l}\text { Ellenanyag-alapú } \\
\text { gátlószerek }\end{array}$ \\
\hline $\begin{array}{l}\text { EGFR } \\
\text { inhibitorok }\end{array}$ & Erlotinib & Cetuximab \\
\cline { 2 - 3 } & Gefitinib & Panitumumab \\
\cline { 2 - 2 } & Afatinib & \\
& Neratinib & Osimertinib \\
& Lapatinib &
\end{tabular}

\begin{tabular}{ll}
\hline RAS \begin{tabular}{l} 
inhibitorok \\
\cline { 2 - 2 }
\end{tabular} & MRT 510 \\
\cline { 2 - 2 } $\begin{array}{l}\text { BR349949 } \\
\text { BRhibitorok }\end{array}$ & ARS-3248 \\
\cline { 2 - 2 } & Vemurafenib \\
\cline { 2 - 2 } & Dabrafenib \\
\hline
\end{tabular}




\section{A kináz-gátlás példája BRAF és EGFR mutációk esetén}

Ahogy már említettük, ahhoz, hogy a RAS fehérje a sejtek osztódási folyamatait szabályozza, össze kell kapcsolódnia más fehérjékkel. Az egyik RAS-hez kapcsolódni képes molekula a BRAF (rapidly accelerated fibrosarcoma B izoforma) enzim (1. ábra). A BRAF feladata, hogy egy foszfátcsoportot rárakjon egy további jeltovábbító molekulára (azon belül is a molekula egy speciális szerin vagy treonin aminosav oldalláncára), és aktiválja azt. A foszfátcsoportok mozgatását végző enzimeket kinázoknak nevezzük. Ha a BRAF kináz aktivitását gátoljuk, akkor nem tudja például továbbítani a RAS molekulák általi sejtosztódást serkentő jeleket. Így nem meglepő talán, hogy miért fordul elő számos ráktípusnál a BRAF mutáció, hiszen kórosan aktív BRAF enzim kórosan aktiválhatja a sejtek osztódását. A BRAF mutáció leggyakrabban melanomák esetén, másodsorban vastagbélrákoknál fordul elő. Kimutatták, hogy a BRAF kináz génjében egy bizonyos aminosavat érintő mutáció (más néven a „V600E mutáció”) onkogén elváltozásokhoz vezet, amelynek következtében a BRAF kináz aktivitása állandósul és RAS kapcsolódás nélkül is képes a sejtosztódást elősegíteni. Ezzel magyarázzák azt a tényt, hogy egyszerre a RAS és a BRAF gén mutációja nincs jelen a ráksejtekben, hiszen elég csak az egyik génen egy aktiváló mutáció, ahhoz, hogy az onkogén folyamatok beinduljanak. Ilyen esetekben az a sejt, melyben a mutáns BRAF kináz jelen van, korlátlanul elkezd szaporodni és az utódsejtek újabb és újabb mutációkat szenvednek, kialakítva ezzel a tumorokban jelen lévő heterogenitást. Logikus volt tehát az az igény, hogy vessünk be olyan molekulákat, amelyek meggátolják a mutáns BRAF kináz konstitutív aktivitását. Az elmúlt húsz év során számos szintetitikus célzott BRAF gátlószert fejlesztettek ki (1. táblázat), amelyek specifikusan kötődnek a mutációt tartalmazó BRAF fehérjéhez, és így meggátolják annak további múködését. A BRAF kináz gátló szereknek komoly szerepük van a BRAF mutációt hordozó melanoma kezelésében, ahol nagy hatékonysággal már ma is alkalmazzák ezeket (1. táblázat). Viszont, a BRAF gátlószerek esetén is igaz, hogy a hatékonyságot nagymértékben befolyásolja, hogy milyen típusú daganatról van szó, valamint hogy milyen más mutációk vannak jelen még a tumorban. A gátlószerek tumorfüggő hatását mutatja, hogy BRAF mutáns melanomák esetén nagyon jó eredményeket lehet elérni BRAF-gátló célzott terápiával, míg BRAF mutációt hordozó vastagbélrákos betegeknél sokkal kevésbé hatékonyak ezek a szerek. Az onkológiában ezért pár éve elterjedt az a terápiás stratégia, hogy egyszerre több jeltovábbító molekula múködését kellene legátolni úgy, hogy kombináljuk a különböző kináz inhibitorokat. Így tesztelés alatt van az a kombinációs kezelés, melyben BRAF mutáns vastagbélrákos esetekben a BRAF gátlás mellé még a jeltovábbítás további molekulát is gátolják (úgymint a MEK kinázt Binimetinib gátló- szerrel és az EGFR fehérjét Cetuximab gátlószerrel), és így hármas blokkolást végeznek, azzal a céllal, hogy a ráksejtek osztódását megállítsák és apoptózist indukáljanak (Ros et al. 2021). A RAS, BRAF fehérjék mellett ugyanis a harmadik nagyon gyakori enzimaktivitású fehérje, amelynek mutációja nagyon erős onkogén hatást okoz, az EGFR fehérje.

Az EGFR (Epidermális Növekedési Faktor Receptor) a sejtek felszínén helyezkedik el és kettős funkciója van. Egyfelől a sejten kívüli térből megköti az EGF molekulát, másfelől a sejten belüli térben lévő receptorrésznek enzimfunkciója is van. Egészséges sejtekben EGF kötést követően az EGFR enzim funkciója aktiválódik, és ekkor az EGFR kináz egy foszfátcsoportot tud áthelyezni tirozin oldalláncokat tartalmazó jeltovábbító molekulákra. Az EGFR kináz funkciójának köszönhetően további jeltovábbító molekulák „lendülnek munkába” a sejten belül, például a RAS útvonalat aktiváló molekulák is, míg a sejt osztódásba kezd. Látható, hogy ha csak ezt a három fehérjét vizsgáljuk (EGFR-RAS-BRAF), már milyen bonyolult összjátéka alakul ki a sejten belüli információáramlásnak és végső soron a sejtosztódás szabályozásának (1. ábra). Ha egy sejtben az EGFR génje olyan mutációt szenved, amelynek következtében az EGFR sejten belüli részén állandóvá válik a kináz-aktivitás, akkor már ennek a sejtnek nincs is szüksége kívülrôl érkező EGF molekulákra, hogy az osztódása felgyorsuljon. EGFR kináz domént érintő mutáció igen gyakori a nem kissejtes tüdőrákok esetén, más ráktípusoknál (glioblastomáknál és vastagbélrákos betegeknél) az extracelluláris részt érintő EGFR mutációk gyakoriak.

Az EGFR gátlására is évtizedek óta terveznek és gyártanak inhibitor molekulákat, melyek között vannak tabletta formájában szedhető, gyomorból könnyen felszívódó gyógyszerek. Az áttörő siker azonban még várat magára az EGFR-gátlást alkalmazó kezelésekben, mert nagyon gyakori a rezisztencia kialakulása EGFR-gátlást követően. Számos mechanizmust „kifejlesztettek” a ráksejtek, hogy kitérjenek az EGFR-gátlás osztódást csökkenető hatása elől, és ezzel a ráksejtek továbbélését biztosítsák a terápia ellenére is. Így tehát ugyan az EGFR gátlószerekkel egy időre „kikapcsolhatjuk” a szabályozás alól kicsúszott tumorsejtek féktelen osztódását, és a beteg állapota átmenetileg javulhat, de ha a tumorsejtekben újra és újra megjelennek mutációk, amelyek biztosíthatják a ráksejtek gátlószer-rezisztens szaporodását, akkor a kináz-gátlás már hatástalan lesz. Az osztódás felgyorsulása a mutációknak kedvez és génamplifikációkhoz is vezet, így a kialakult újabb mutációkat és az érintett szabályozatlan jelpályákat kell újabb kezelésekkel terápiásan megcélozni.

Az EGFR a sejtek felszínén a membránon átívelve helyezkedik el, és a sejten belüli múködéséhez elengedhetetlen a kívülről érkező EGF ligandum kötődése. Így EGFR gátláshoz kétféle stratégia is rendelkezésre áll: (1) az EGFR-t túltermelő tumorok esetén érdemes az EGFR külső felszínét blokkolni, míg (2) az EGFR sejten 
belüli részét érintő mutációknál a kináz-aktivitást blokkoló szerek járhatnak sikerrel (1. ábra). Első esetben, amikor a ligandum bekötődését kell legátolni, akkor EGFR-hez szelektíven kapcsolódó ellenanyag-terápiát alkalmaznak (1. táblázat). Ha az EGFR kináz aktivitását kell a mutáció miatt blokkolni, akkor pedig szintetikus kis molekulák a hatékonyak, melyek szelektíven képesek a mutált EGFR funkcióját legátolni (Meisel-Hochmair 2020).

\section{A TRK fúziós fehérje gátlása}

A TRK fúziós fehérjecsalád három neurotropin tirozinkináz receptort tartalmaz, a TRKA-t, a TRKB-t és a TRKC-t, amelyeket az NTRK1, az NTRK2 és az NTRK3 gének kódolnak. Ezen gének elsődleges élettani szerepe a neuronok növekedésében, differenciálódásában van, azonban már 1986-ban leírták, hogy a tumorok kialakulásában is részt vesznek (Martin-Zanca et al. 1986). Az onkológiai hatással rendelkező fehérje két másik gén, egy rövidebb tropomyozin és egy protein kináz szekvencia egymás mellé kerülése által jön létre, ezért úgynevezett "fúziós onkogénnek” is nevezik.

A létrejött fúziós fehérje kikapcsolhatatlanul aktivált állapotba kerül. Az általa elindított jelátviteli utak között van a PI3K/AKT/MTOR és a RAS/RAF/MEK/ERK útvonal, és a PLCg/DAG/PKC/MEK/ERK útvonalak. Ezen útvonalak olyan további gének múködését kapcsolják be, amelyek a tumorsejtek szaporodását és túlélését segítik, fokozzák az áttétképzést és a tumor-indukálta érújdonképződést (2. ábra).

A TRK fúziós fehérjék onkológiai hatását számos tumor esetén leírták, amelynek során a különböző NTRK gének sok esetben eltérő tumortípus kialakulásához vezettek. Az NTRKl megjelenését megfigyelték kolontumor, tüdőtumor, agytumorok, hasnyálmirigyrák, melanoma, emlőtumor és szarkómák esetén. Az NTRK2 fúziós fehérjék gyermekkori agytumorokban, fej- és nyaki tumorokban, kolontumorban, tüdőtumorban és asztrocitómákban fordultak elő. Az NTRK3 felnőttkori és gyermekkori központi idegrendszeri tumorokban, szarkómákban, fej- és nyaki tumorokban és leukémiákban fordult elö.

Ki kell azonban emelni, hogy a sok tumorban való elöfordulás nem jelenti egyúttal azt, hogy a TRK fúziós fehérjék gyakoriak lennének. Felnőttkori tumorok esetén a tüdőtumorok 0,2-3\%-a, a kolontumorok 1,5\%-a, a melanomák $0,3 \%$-a, a pajzsmirigy rosszindulatú tumorok 1,5-14\%-a, és a májon belüli cholangiocarcinoma 3,6\%-a tartalmaz valamilyen TRK fúziós fehérjét. Bizonyos gyermekkori tumorok esetén jóval magasabb az előfordulás: a csecsemókori firboszarkómában 91-100\%-ban van jelen (Bourgeois et al. 2000), a veleszületett vesetumorok 83\%-ában (Rubin 1998), és az agytörzsön kívüli gliómák 7,1\%-a (Wu et al. 2014) tartalmaz TRK fúziós fehérjét. Ezen előfordulási mintázat alapján két fontos következtetést vonhatunk le: egyrészt bizonyos tumortí- pusokban magas az előfordulás, és ezért ott a célzott terápiás megközelítések optimális célpontja lehet. Más tumorokban viszont ritka, és bár emiatt általános kezelésre nem alkalmazható, azonban még a ritka előfordulás mellett is vannak olyan betegek, akik kaphatnának egy megfelelö célzott terápiát.

Főleg ezen második esetben a terápiát csak úgy érdemes elképzelni, hogy csak azon betegek kapják meg a megfelelő kináz-gátló kezelést, akiknek a daganatmintáiból a fúziós fehérje kimutatható. Szerencsére ilyen célzott terápia ma már rendelkezésre áll, és a Larotrecinib (LOXO-101) volt 2019-ben az első olyan onkológiai gyógyszer, amelyet kizárólag a molekuláris eltérések alapján, a tumor szövettani típusától függetlenül jóváhagytak. A Larotrecinib vizsgálatába (Drilon 2018) öszszesen 55 beteget vontak be, akikben a legkülönbözőbb, már előrehaladott stádiumban levő daganatok alakultak ki, mint például tüdőtumor, emlőrák, nyálmirigyrák, hasnyálmirigyrák, kolontumor, melanoma vagy pajzsmirigyrák. Azonban valamennyi tumor közös jellemzője volt a TRK fúziós fehérjék jelenléte. A betegeket Larotrectinibbel, egy szájon át szedhető TRKA+TRKB+TRKC gátlószerrel kezelték, amely 100-szor erősebben kötődik a TRK kinázokhoz, mint más kinázokhoz.

\section{TRK fúziós fehérje}

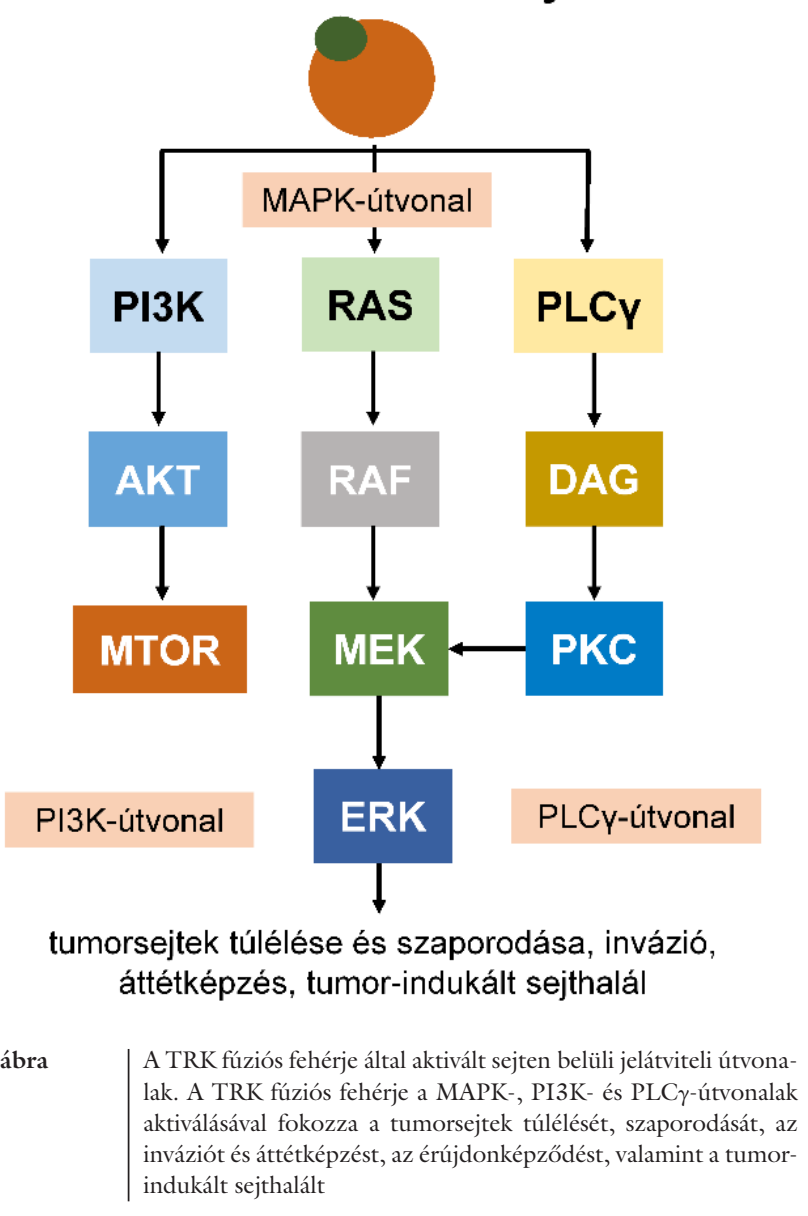


A vizsgálatban tapasztalt hatás drámai volt: a betegek 80\%-ában csökkent a tumorméret a kezelés hatására. A tumor növekedésére kifejtett gátló hatás egy év után is a betegek $71 \%$-ában jelen volt, és a betegek 55\%-ában nem volt progresszió. Összesen 11 olyan beteg volt, akiben a tumor teljesen eltűnt. Az összes bevont betegból mindössze négy esetben figyeltek meg progressziót a kezelés után. Ezen kiemelkedő eredmények alapján már az alacsony betegszám ellenére is jóváhagyták a Larotrectinib klinikai alkalmazását.

Amint fentebb említettük, a TRK fúziós fehérjék előfordulása bizonyos gyermekkori tumorok esetén volt a legmagasabb. A TRK fúziós fehérjék gátlásának terápiás hasznát gyermekkori szolid tumorok esetén is tanulmányozták (Laetsch 2018). A klinikai vizsgálatba 1-21 év közötti gyermekeket vontak be, akikben előrehaladott tumort vagy áttétet diagnosztizáltak, vagy pedig visszatérő központi idegrendszeri daganatban szenvedtek. Sok gyermekkori tumor (például leukémiák) jól reagál a hagyományos kemoterápiára, azonban a gyermekkori központi idegrendszeri tumorok esetén nem áll rendelkezésre hatékony molekuláris célzott terápia, ezért a sebészet jelenti jelenleg a betegek számára az egyetlen lehetőséget. A TRK-gátlást csak olyan betegekben próbálták ki, akiknek megfelelő máj- és vesefunkciójuk volt, és már teljesen felépültek a korábbi kezelések esetleges toxikus hatásaiból.

A vizsgálatba 15 TRK fúziós fehérjével rendelkező beteg mellett négy fúziós fehérjével nem rendelkező beteget is bevontak. A TRK fúziós fehérjével rendelkező tumorok mindegyike vagy fibroszarkóma, vagy kötőszövet-szarkóma volt, és legalább 30\%-os tumorcsökkenést mutattak fel, miközben a TRK fúzióval nem rendelkezó betegek egyikénél sem volt szignifikáns javulás. A hatás független volt attól, hogy NTRK1, NTRK2 vagy NTRK3 volt a fúziós fehérje TRK része, és a tumor szövettani típusa szerint sem volt eltérés a betegek válaszadási arányában (Laetsch et al. 2018).

A korlátozott betegszám ellenére mindkét fentebb leírt vizsgálatban magas hatásosságot ért el a Larotrectinib kezelés. Mindezen vizsgálatok alapján nemcsak a kinázgátló kezelés javasolható a TRK fúziós fehérjék jelenléte esetén, azonban a kimagasló eredmények azt is felvetik, hogy a kinázgátlókat már a tumor gyógyszeres kezelésének egy korábbi fázisában, más szóval a tumor elsővonali kezelésében is érdemes lenne kipróbálni.

\section{Saját kutatásaink agytumoros páciensek kinázgátlással történő kezelésére}

Az elsődleges agydaganatok között leggyakrabban előforduló előrehaladott gliómákhoz rossz kimenetel társul a hatékony terápiás beavatkozás hiánya és a daganat gyakori kiújulásának következtében. A felnőttek körében a leggyakrabban előforduló glioblastoma multiforme (GBM) az elsődleges agydaganatok csaknem felét teszi ki, és IV-es fokozatú, azaz a súlyos lefolyású kategóriába tartozik.

A sebészeti eljárást, sugár- és kemoterápiát is magába foglaló terápia ellenére a túlélés alacsony, klinikai vizsgálatokban a medián túlélés 14-17 hónap, az általános populáción alapuló tanulmányokban 12 hónap, míg az ötéves túlélés mindössze 5,6\%-os (Reifenberger et al. 2017).

A széles körú molekuláris vizsgálatok ellenére, melyek elsősorban a tumorban megtalálható metilációs mintázatra, génmutációkra, a kópiaszám-változásra és onkológiai jelátviteli útvonalak aktivitására fókuszáltak, a glioblastoma eredete és kialakulásának folyamata nem teljesen ismert. A klinikumban mindössze néhány biomarker segíti a terápiás döntést. A glioblastomák kb. 10\%-ában fordul elő az IDHl/2 gének mutációja, melynek jelenléte jobb klinikai kimenetelt jelent ( an et al. 2019). A terápiás döntésben ezenfelül kulcsfontosságú az O6metilguanin-DNS metiltranszferáz (MGMT)-promóter metilációja. Az MGMT a DNS hibajavításban szerepet játszó enzim termeléséért felelős. Metilált MGMT-promóter jelenlétében az epigenetikus csendesítés hatására az enzim termelődése gátlódik, így az egyes kemoterápiás kezelésben alkalmazott alkilálószerek, például a temozolomid (TMZ) hatékonyabban fejtik ki hatásukat (Hegi et al. 2015). Ennek megfelelően 2005-ben jóváhagyásra került a sugárterápiával egy időben alkalmazott, majd az azt követő TMZ terápia alkalmazása újonnan diagnosztizált felnőttkori glioblastoma kezelésére. Előnyösebb stratégia hiányában a markerrel nem rendelkező - vagyis nem metilált MGMT-promóter jelenlétében - jó általános állapotú, 70 év alatti glioblastoma páciensek is TMZ terápiában részesülnek.

Nagy problémát jelent azonban, hogy nem minden MGMT-metilációval azonosított páciens reagál a TMZ terápiára, illetve a kezdeti javulást csaknem minden esetben visszaesés követi. A visszaeső betegek kezelésére irányuló törekvések sajnos mind ez idáig sikertelenek. A jelenlegi kemoterápiás szerek limitált alkalmazhatósága új, célzott megközelítések fejlesztését tette szükségessé.

Csaknem minden súlyos lefolyású kategóriába tartozó gliómában előfordul valamely tirozin-kináz receptor útvonalat érintő genetikai eltérés, bár felnőttek és gyermekek esetében ezek típusa és előfordulási gyakorisága eltérő (Parsons et al. 2008). A sejtfelszínen előforduló, különböző tirozin-kináz receptorcsaládba (pl. PDGFcsalád, EGFR, ErbB2, ErbB3, ErbB4, VEGFRl-4, FGFRl-3 és a c-MET) tartozó receptorok túlzott aktivitását okozhatja többek között a receptort kódoló gén amplifikációja és felülexpresszálódása, a gének mutációja, a receptorok ligand-független összekapcsolódása vagy a receptort aktiváló ligandok felülexpresszálódása. Felnőttkori súlyos lefolyású gliómákban a sejtfelszínen található EGFR-receptor a leggyakrabban amplifikált vagy mutálódott onkogén és egyéb tumorokban (pl. nem kissejtes tüdő karcinóma) ennek célzott gátlása sikeresen alkalmazott terápia (Siegelin-Borczuk 2014). Az EGFR ígéretes szerepe miatt számos klinikai vizsgálat fókuszál 
az EGFR útvonal célzott gátlására glioblastomában, azonban ezek a törekvések mind ez idáig hatástalannak bizonyultak. Ennek oka, hogy glioblastomákban gyakran az EGFR receptor extracelluláris szakaszát érinti deléció, mely ligandfüggetlen aktivitáshoz vezet.

Kezdetben ugyancsak ígéretesnek tünt egy VEGF-t célzó antitest, a bevacizumab kombinációja sugár- és TMZ-terápiával, azonban a késői, nagy betegszámmal lefolytatott (fázis III-as) klinikai vizsgálatok eredményei nem váltották be a kezdeti reményeket (Chinot et al. 2014). Ugyancsak hatástalannak bizonyultak újonnan diagnosztizált betegekben további, viszonylag gyakran érintett útvonalak (Akt, mTOR, TP53, RB) gátlására irányuló törekvések is (Le Rhun 2019). Sajnos glioblastoma kezelésére alkalmas tirozin kináz-gátlószer a mai napig nem került jóváhagyásra.

Nagy szükség van tehát olyan biomarkerekre, melyek alkalmasak a terápiás kezelés hatékonyságának előrejelzésére, illetve új terápiás célpontok és lehetséges kombinációs terápiák azonosítására. A terápiás válasz előrejelzésére kutatócsoportunk egy szabadon elérhető elemzőrendszert (rocplotter.com) dolgozott ki, melynek alapja, hogy a kezelést megelőzően elemzi a tumorszövetből származó teljes génexpressziós mintázatot a későbbi kezelésre adott válasz függvényében. A rendszer segítségével elkülöníthetők a terápiára reagáló, illetve nem reagáló betegek, és mindkét kimenet esetében meghatározhatók a magasan kifejeződő gének (Menyhárt 2021).

Az elemzést különböző kemoterápiás szerekkel kezelt glioblastomás betegek esetében végeztük el. Külön figyelmet fordítottunk azokra a kezelésre nem reagáló betegekre, akik csak TMZ-t vagy csak nitrosoureát kaptak, illetve azokra, akik TMZ-nitrosourea kombinált kezelésben részesültek. Minden így elkülönített betegcsoportban megvizsgáltuk a magasan kifejeződő gének mintázatát. A kezelésre nem reagáló betegekben azonosított magasan expresszálódó gének közül három (PDGFA, FGFR3 és IGFBP3) rendelkezik tirozin-kináz aktivitással. A kezelés előtti tumorszövetben magas PDGFA és FGFR3 expresszió jellemezte a később nitrosoureával kezelt, de kezelésre nem reagáló betegeket. Magas IGFBP3 expresszió a kombinált TMZ terápiára nem reagáló, 55 évnél fiatalabb betegcsoportban volt mérhető (Menyhárt 2021).

Az általunk azonosított mindhárom gén lehetséges terápiás szerepe már felmerült a szakirodalomban. A rossz klinikai kimenettel társuló FGFR3-TACC3 génfúzió a leggyakrabban előforduló FGFR receptorokat érintő elváltozás, melyet kisszámú páciens esetében erdafitinibbel, egy pán-FGFR kinázgátlóval kezeltek (Stefano et al. 2015). A magas IGFBP3 expresszió rövidebb túléléssel és súlyosabb lefolyású betegséggel társult 135 újonnan diagnosztizált páciens esetében, míg a csökkent IGFBP3 szint lassította a tumoros sejtek osztódását és fokozta a sejthalál mértékét sejtkultúrás kísérletekben és egerekben létrehozott humán eredetú kísérletes daganatokban (Chen et al. 2020). A PDGF-receptor útvonal megnöve- kedett aktivitása, ezen belül is a PDGFA magas expreszsziója a glioblastoma kialakulásának egyik feltételezett kiindulási eleme.

Eredményeink alapján tehát az azonosított gének magas kifejeződése segítséget nyújthat azon betegek kiszürésére, akik feltehetőleg rosszul reagálnának a konvencionális TMZ-alapú, illetve kombinált (TMZ-nitrosourea) kezelésekre. A legfontosabb eredményünk azonban az, hogy ezen betegek esetében eredményeink lehetőséget nyújtanak tirozin-kináz gátlókkal kombinált kezelések alkalmazására jövőbeni klinikai vizsgálatokban.

\section{Kitekintés}

Összefoglalónkban rövid áttekintést adtunk a személyre szabott tumorterápia legújabb lehetőségeiról, úgymint a RAS, EGFR, BRAF, TRK fúziós fehérjék vagy az FGFR molekulák célzott terápiás gátlásáról. Elmondható, hogy minél többet megtudunk a tumorsejtekben végbemenő molekuláris szintű elváltozásákról, annál precízebben tudjuk majd meghatározni, hogy a betegeknél milyen tipusú egyéni kezeléssel vagy kombinált terápiával lehetne gyógyulást elérni. Ugyanakkor az egyre bővülő tudásunk arra is rávilágít, hogy ez még csak a kezdete a személyre szabott molekuláris onkológiának. A tumorsejtek „leleményes túlélési stratégiáit” kell több irányból megcélozni és ez a feladat több tudmányterület összefogásával tud majd csak megvalósulni: a tumorok precíz diagnosztikájával és prognosztikai markerek kimutásának fejlődésével, a korai tumorfelismeréssel és a gyógyszeres kezelések megfelelő kombinációjával.

\section{Köszönetnyilvánítás}

Az összefoglaló elkészítését a következő támogatások tették lehetővé: Buday László pályázatai (OTKA K 124045, FIEK_16-1-2016-0005, HunProtEx 20181.2.1-NKP-2018-00005, és a MedinProt Program), Győrffy Balázs pályázatai (2018-2.1.17-TET-KR-00001, 2018-1.3.1-VKE-2018-00032 és 2020-4.1.1.-TKP2020) és Menyhárt Otília pályázatai (Nemzeti Bionika Program). Külön köszönetet mondunk A. Blake Williams angol nyelvi szerkesztő segítségéért és Takács Tamásnak az első ábra elkészítésért.

\section{Irodalomjegyzék}

Bourgeois, J. M., Knezevich, S. R., Mathers, J. A., \& Sorensen, P. H. B. (2000) Molecular Detection of the ETV6-NTRK3 Gene Fusion Differentiates Congenital Fibrosarcoma From Other Childhood Spindle Cell Tumors. The American Journal of Surgical Pathology, Vol. 24. No. 7. pp. 937-946.

Buday, L., \& Downward, J. (1993) Epidermal growth factor regulates p2lras through the formation of a complex of receptor, Grb2 adapter protein, and Sos nucleotide exchange factor. Cell, Vol. 73. No. 3. pp. 611-620. 
Buday, L., \& Vas, V. (2020) Novel regulation of Ras proteins by direct tyrosine phosphorylation and dephosphorylation. Cancer Metastasis Rev., Vol. 39. No. 4. pp. 1067-1073.

Chinot OL, Wick W, Mason W, Henriksson R, Saran F, Nishikawa R, et al. (2014) Bevacizumab plus Radiotherapy-Temozolomide for Newly Diagnosed Glioblastoma. New England Journal of Medicine. 2014 370(8): pp. 709-22.

Drilon, A., Laetsch, T. W., Kummar, S., DuBois, S.G., Lassen, U. N., Demetri, G. D., ... Hyman, D. M. (2018) Efficacy of Larotrectinib in TRK Fusion-Positive Cancers in Adults and Children. New England Journal of Medicine, Vol. 378. No. 8. pp. 731-739.

Flaherty, K. T., Gray, R., Chen, A., Li, S., Patton, D., Hamilton, S. R., ... NCI-MATCH Team (2020) The Molecular Analysis for Therapy Choice (NCI-MATCH) Trial: Lessons for Genomic Trial Design. J Natl Cancer Inst. Vol. 112. No. 10. pp. 1021-1029.

Gieszer, B., Megyesfalvi, Z., Dulai, V., Papay, J., Kovalszky, I., Timar, J., ... Moldvay, J. (2021) EGFR variant allele frequency predicts EGFR-TKI efficacy in lung adenocarcinoma: a multicenter study. Transl Lung Cancer Res. Vol. 10. No. 2. pp. 662-674.

Hegi, M. E., Diserens, A.-C., Gorlia, T., Hamou, M.-F., de Tribolet, N., Weller, M., ... Stupp, R. (2005) MGMT Gene Silencing and Benefit from Temozolomide in Glioblastoma. New England Journal of Medicine, Vol. 352. No. 10. pp. 997-1003.

Chen C, Chen P, Lin Y, Feng L, Chen S, Chen C, et al. Suppression of tumor growth via IGFBP3 depletion as a potential treatment in glioma. Journal of Neurosurgery. 2020132 (5):pp. 1313-1674.

Laetsch, T. W., DuBois S. G., Mascarenhas, L., Turpin, B., Federman, N., Albert, C. M., ... Hawkins, D. S. (2018) Larotrectinib for paediatric solid tumours harbouring NTRK gene fusions: phase 1 results from a multicentre, open-label, phase $1 / 2$ study. The Lancet Oncology, Vol. 19. No. 5. pp. 705-714.

Le Rhun, E., Preusser, M., Roth, P., Reardon, D. A., van den Bent, M., Wen, P., ... Weller, M. (2019) Molecular targeted therapy of glioblastoma. Cancer Treatment Reviews, 80:101896.

Martin-Zanca, D., Hughes, S. H., \& Barbacid, M. (1986) A human oncogene formed by the fusion of truncated tropomyosin and protein tyrosine kinase sequences. Nature, Vol. 319. No. 6056. pp. 743-748.

Meisel, A., \& Hochmair, M. (2020) Critical Review of EGFR-Mutated NSCLC: What We Do and Do Not Know. healthbook TIMES Onco Hema. Vol. 18. No. 3. pp. 20-35.

Menyhárt, O., Tibor Fekete, J., \& Győrffy, B. (2021) Gene expression-based biomarkers designating glioblastomas resistant to multiple treatment strategies. Carcinogenesis, Vol. 42, Issue 6, 2021, pp. 804-813.
Moore, A. R., Rosenberg, S. C., McCormick, F., \& Malek, S. (2020) RAS-targeted therapies: is the undruggable drugged? Nature Reviews Drug Discovery, Vol. 19. No. 8. pp. 533-552.

Ozawa, T., Riester, M., Cheng, Y.-K., Huse, J. T., Squatrito, M., Helmy, K., ... Holland, E. C. (2014) Most Human Non-GCIMP Glioblastoma Subtypes Evolve from a Common Proneural-like Precursor Glioma. Cancer Cell, Vol. 26. No. 2. pp. 288-300.

Parsons, D. W., Janeway, K. A., Patton, D., Coffey, B., Williams, P. M., Hamilton, S. R., ... Seibel, N. (2019) Identification of targetable molecular alterations in the NCI-COG Pediatric MATCH trial. JCO. Vol. 37. No. 15. suppl. 10011.

Parsons, D. W., Jones, S., Zhang, X., Lin, J. C.-H., Leary, R. J., Angenendt, P., ... Kinzler, K. W. (2014) An Integrated Genomic Analysis of Human Glioblastoma Multiforme. Science, Vol. 321. No. 5897. pp. 1807-1812.

Reifenberger, G., Wirsching, H.-G., Knobbe-Thomsen, C. B., \& Weller, M. (2017) Advances in the molecular genetics of gliomas implications for classification and therapy. Nature Reviews Clinical Oncology, Vol. 14. No. 7. pp. 434-452.

Ros, J., Baraibar, I., Sardo, E., Mulet, N., Salvà, F., Argilés, G., ... Élez. E. (2021) BRAF, MEK and EGFR inhibition as treatment strategies in BRAF V600E metastatic colorectal cancer. Ther Adv Med Oncol., 13: 1758835921992974.

Rubin, B. P., Chen, C.-J., Morgan, T. W., Xiao, S., Grier, H. E., Kozakewich, H. P., ... Fletcher, J. A. (1998) Congenital Mesoblastic Nephroma t(12;15) Is Associated withETV6-NTRK3 Gene Fusion: Cytogenetic and Molecular Relationship to Congenital (Infantile) Fibrosarcoma. The American Journal of Pathology, Vol. 153. No. 5- pp. 1451-1458.

Siegelin, M. D., \& Borczuk, A. C. (2014) Epidermal growth factor receptor mutations in lung adenocarcinoma. Laboratory Investigation, Vol. 94. No. 2. pp. 129-137.

Stefano, A. L. D., Fucci, A., Frattini, V., Labussiere, M., Mokhtari, K., Zoppoli, P., ... Iavarone, A. (2015) Detection, Characterization, and Inhibition of FGFR-TACC Fusions in IDH Wild-type Glioma. Clin Cancer Res., Vol. 21. No. 14. pp. 3307-3317.

Vogelstein, B., Papadopoulos, N., Velculescu, V. E., Zhou, S., Diaz, L. A., \& Kinzler, K. W. (2013) Cancer Genome Landscapes. Science, Vol. 339. No. 6127. pp. 1546-1558.

Wu, G., Diaz, A. K., Paugh, B. S., Rankin, S. L., Ju, B., Li, Y., ... Baker, S. L. (2014) The genomic landscape of diffuse intrinsic pontine glioma and pediatric non-brainstem high-grade glioma. Nature Genetics, Vol. 46. No. 5. pp. 444-450.

Yan, H., Parsons, D. W., Jin, G., McLendon, R., Rasheed, B.A., Yuan, W., ... Bigner, D. D. (2009) IDH1 and IDH2 Mutations in Gliomas. New England Journal of Medicine, Vol. 360. No. 8. pp. 765773

A cikk a Creative Commons Attribution 4.0 International License (https://creativecommons.org/licenses/by/4.0/) feltételei szerint publikált Open Access közlemény, melynek szellemében a cikk bármilyen médiumban szabadon felhasználható, megosztható és újraközölhető, feltéve, hogy az eredeti szerző és a közlés helye, illetve a CC License linkje és az esetlegesen végrehajtott módosítások feltüntetésre kerülnek. (SID_1) 